\title{
A TECNOLOGIA: ALGUMAS REFLEXÕES SOCIOESPAÇO-TEMPORAIS ${ }^{1}$
}

\author{
Donarte Nunes dos Santos Júnior ${ }^{2}$, Regis Alexandre Lahm ${ }^{3}$
}

\section{Resumo}

O presente artigo propõe algumas reflexões sobre as sutis e específicas nuanças que se verificam na relação entre a tecnologia e as configurações socioespaciais. Tais aspectos se referem às alterações espaço-temporais ocasionadas pelos implementos tecnológicos, bem como, à forma como é estruturada e mantida a distribuição destes avanços. Para tanto, o texto (re)toma conceitos de raiz, apontando para algumas imprecisões quanto ao entendimento acerca das técnicas e das tecnologias, passando por questões midiáticas e epistemológicas.

Palavras-chave: Tecnologia, Espaço, Transformação Espaço-temporal, Velocidade.

\begin{abstract}
The present article proposes some reflections about the subtle and specific nuance verified in the relation between technology and sociospacial configurations. Such aspects refer to spatial-temporal alterations caused by technological implements, as well to the way how the distribution of this advancement is built and maintained. Then, this text (re)takes root concepts, pointing to some imprecision towards the knowledge about techniques and technologies, going through mediatic and epistemological issues.
\end{abstract}

Keywords: Technology, Space, Space-temporal Transformation, Velocity.

\footnotetext{
${ }^{1}$ Avanços reflexivos feitos a partir de uma dissertação de mestrado apresentada à Faculdade de Física, Programa de Pós-Graduação em Educação em Ciências e Matemática: SANTOS JÚNIOR, Donarte Nunes. Geografia do espaço percebido: uma educação subjetiva. 280 f. Dissertação (Mestrado em Educação em Ciências e Matemática), Faculdade de Física, PUCRS, Porto Alegre, 2007, disponível, também, em: http://tede.pucrs.br/tde_busca/arquivo.php?codArquivo=974.

${ }^{2}$ Mestre em Educação em Ciências e Matemática, Pontifícia Universidade Católica do Rio Grande do Sul (PUCRS). Porto Alegre, RS. <donarte.santos@pucrs.br>.

${ }^{3}$ Doutor em Recursos Hídricos e Saneamento Ambiental, Pontifícia Universidade Católica do Rio Grande do Sul (PUCRS). Porto Alegre, RS. <lahm@pucrs.br>.
} 
"Todo o nosso progresso tecnológico, que tanto se louva, o próprio cerne de nossa civilização, é como um machado na mão de um criminoso.".

(Einstein, 1980, p. 114)

\section{Introdução}

Assunto corrente nos dias de hoje, a tecnologia está presente tanto em conversas e opiniões de senso comum ${ }^{4}$, quanto nos debates dos círculos científicos. Ao se escrever sobre tecnologia, outros conceitos acabam por acompanhar a análise e não podem ficar para trás, intocados. Sendo assim, temas e termos como Revolução Industrial, Globalização, e informação fazem parte das observações subseqüentes.

O presente artigo está dividido em três tópicos. O primeiro aborda noções a respeito do conceito de tecnologia. O segundo, questões relativas ao surgimento, evolução e função da tecnologia. Por fim, espacialização da tecnologia é assunto do quarto tópico.

\section{Conceito de Tecnologia}

Buscando-se o significado da palavra tecnologia, tem-se que ela provém da junção dos termos gregos techne (arte) + logos (tratado). Seu equivalente em latim mais próximo é ars ou artis, ambos significando "arte", ou ainda, a habilidade adquirida a partir de um estudo ou prática. Segundo Pinto ${ }^{5}$ (2005), existem pelo menos quatro acepções para o termo. O primeiro sentido diz respeito à "arte" designando a "teoria, a ciência, o estudo, a discussão da técnica, abrangidas nesta última noção as artes, as habilidades do fazer, as profissões [...]” (p. 219). O segundo significado do termo remete à simples técnica, sinônimo do saber fazer, ou ainda, "know how" (p. 219). A terceira significação equivale à união de todas, ou seja, o "conjunto

\footnotetext{
${ }^{4}$ Segundo Morais (1988) senso comum é o conhecimento vulgar, sendo que: "usa-se também dar a essa modalidade de conhecimento o nome de empírico. [...] Platão, na Antiga Grécia, já fazia distinção entre três tipos de conhecimento: doxa (opinião, saber não provado, saber do povo), episteme e sofia (saberes especiais dos homens mais refletidos e estudados, correspondendo, o primeiro ao conhecimento tido naquele tempo como científico; o segundo, a toda a sabedoria dos 'primeiros princípios' acumulada pela filosofia)." (p. 25-27). Porém, os presentes autores gostariam de deixar claro não estar com isso desdenhando o senso comum, pois, conhecem, entre outras coisas, a opinião de Freire (1992): "Possivelmente foi a convivência sempre respeitosa que tive com o 'senso comum', desde os idos de minha experiência no Nordeste brasileiro, a que se junta a certeza de que em mim nunca fraquejou de que sua superação passa por ele, que me fez jamais desdenhá-lo ou simplesmente minimizá-lo. Se não é possível defender uma prática educativa que se contente em girar em torno do 'senso comum', também não é possível aceitar a prática educativa que, zerando o 'saber de experiência feito', parta do conhecimento sistemático do(a) educador(a).” (58-59).

${ }^{5}$ PINTO, Álvaro Vieira. O Conceito de Tecnologia. Rio de Janeiro: Contraponto, 2005. 1v. Neste denso tratado composto por dois volumes, Álvaro Vieira Pinto (filósofo e matemático brasileiro) escreve sobre a tecnologia. As observações, porém, sobre a origem do termo e as diversas acepções possíveis, encontram-se às páginas 174 a 185 e 219 a 346 do primeiro volume.
} 
de todas as técnicas de que dispõe uma determinada sociedade, em qualquer fase histórica de seu desenvolvimento" (p. 219). Por fim, a última compreensão está associada à "ideologia das técnicas” (p. 219). Este último sentido, mais amplo e menos ingênuo, deriva da soma dos termos techne (arte) + logos (palavra, fala, razão) e remete ao que seria uma ideologia ${ }^{6}$ que há por trás das técnicas.

Faz-se necessária uma diferenciação entre técnica e tecnologia. Segundo Vesentini (2005), técnica é o uso que se faz de instrumentos, de ferramentas o que implica a habilidade e a inteligência humanas. Já tecnologia vai além da técnica, implicando o "uso de conhecimento científico, da ciência moderna que nasceu - ou se consolidou - nos séculos XVII e XVIII e prossegue até nossos dias”.(p. 23). Pinto (2005), especificamente a respeito da técnica, escreve que:

\begin{abstract}
A principal confusão envolvente da consciência simplista quando trata da técnica consiste em considerá-la uma substância, um objeto, ao qual é lícito atribuir efeitos, como se estivéssemos em face de uma "coisa", e até, em casos de extremo desordenamento, de uma pessoa. A expressão imediata desse engano encontra-se no emprego, já agora inerradicável, da palavra "técnica" com o valor gramatical de substantivo abstrato. Tal maneira de falar, embora hoje impossível de ser eliminada em razão da fixação vernacular, tem por origem um mal-entendido. A palavra

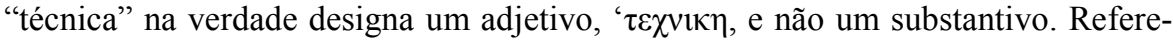
se a um verdadeiro substantivo, a "tecne", " $\tau \dot{\chi} \chi v \eta ́$, traduzido pelos latinos em sentido geral por "ars", arte. Entretanto, aparece igualmente a fórmula latinizada "techna", de uso extremamente raro, com o sentido de "astúcia", "manha", quase certamente por influência do substantivo "technicus", que mais se aproxima do grego, designando o mestre de algum ofício artesanal. A conotação indiscutivelmente desprezível do segundo termo, aplicável quase sempre à escravos, proscreveu o emprego da tradução de "tecne" por "tecna", afirmando a preferência por "ars". Por motivos de caráter semântico acabou impondo-se o adjetivo "técnico(a)", revestido da categoria gramatical de substantivo, assim se conservando nas línguas modernas. (PINTO, 2005, p. 174-175).
\end{abstract}

Constata-se que, atualmente, o termo "técnica" guarda pouca relação com o termo original grego techne ${ }^{7}$, sendo este último bem mais amplo. Sobre a tecnologia, especificamente, Pinto (2005) esclarece que:

Há sem dúvida uma ciência da técnica, enquanto fato concreto e por isso objeto de indagação epistemológica. Tal ciência admite ser chamada tecnologia. Embora não seja freqüente esse modo de entender a palavra revela-se legítimo, por ser o que transporta o significado radical, primordial. (PINTO, 2005, p. 220).

\footnotetext{
${ }^{6}$ Ideologia posta aqui no sentido de legitimação de algum processo, ou ainda, como explica Chauí (1997): "Esse ocultamento da realidade social [...]. Por seu intermédio, os homens legitimam as condições sociais de exploração e de dominação, fazendo com que pareçam verdadeiras e justas.”. (p. 21). Conforme Chaú (1997), a ideologia "possui razões muito determinadas para surgir e se conservar, não sendo um amontoado de idéias falsas [...] mas uma certa maneira da produção das idéias [...] por formas históricas determinadas [...]" (p. 31). A mesma autora conclui que: "A ideologia consiste precisamente na transformação das idéias da classe dominante para a sociedade como um todo, de modo que a classe que domina no plano material (econômico, social e político) também domina no plano espiritual (das idéias)." (p. 93-94).

7 Para ir além, consultar o verbete techne à página 897 no DICIONÁRIO DE FILOSOFIA DE CAMBRIDGE. São Paulo: Paulus, 2006.
} 
Conclui-se, em concordância com Pinto (2005), que o conceito de tecnologia menos ingênuo é o de "ideologia das técnicas". Sabe-se, no entanto, que na forma como é frequentemente usado, remete à noção de "ciência da técnica". A confusão se dá porque as pessoas fazem uso do termo indiscriminadamente e sem a devida reflexão sobre o que seja. Para Pinto (2005), o termo é usado "a todo o momento por pessoas das mais diversas qualificações e com propósitos diferentes" (PINTO, 2005, p. 219), sendo considerados, erradamente, como sinônimos.

\section{Surgimento, Evolução e Função da Tecnologia}

Atualmente, o homem utiliza avançadas tecnologias. Papert (1994), no século passado, já escrevia: “[...] ouve-se dizer que estamos adentrando na Era da Informática.” (p. 9). O avanço tecnológico que se verifica, no entanto, nem sempre foi assim. Ao longo da história, o homem obrigou-se a utilizar várias técnicas para subsistir. Não poderia ser diferente, visto que o homem é, comparado a outros animais do planeta, mais fraco. Segundo Morais (1988), a técnica, e também a ciência, surgem em virtude do medo:

Imaginemos o homem das eras primitivas vivendo sempre ameaçado pelas forças
brutais da natureza, sem edificações para se proteger, distanciado por milhares de
anos dos pára-raios, destituído de recursos de vestuário que o abrigassem mais
completamente. Imaginemo-lo aterrado ante os formidáveis animais que passeavam
sua fericidade pela superfície da Terra. Este terror e esta impotência certamente
terão levado os primitivos a intuírem algo fundamental: ou eles adquiriam PODER
ou seriam esmagados pelo PODER das forças naturais. (MORAIS, 1988, p. 48-49).

O medo e a necessidade levaram o homem a usar ferramentas para sua subsistência, o que se tornava indispensável ante um mundo hostil. Foram, segundo Morais (1988), o medo e a necessidade de poder que conduziram o homem à técnicas cada vez mais apuradas. Para Brüseke (2001), essa é, em última análise, a forma, a "maneira como o homem apropria-se e aproxima-se da natureza".(p. 62).

Esse "poder" almejado pelo homem manifesta-se recentemente na tecnologia. Segundo Vesentini (2005), a partir do final da década de 1970, a humanidade vem presenciando avanços e inovações tecnológicas em ritmo acelerado. Sabe-se que muitos nomes têm sido usados para designar a evolução tecnológica. Conforme Vesentini (2005), é possível se falar em Terceira Revolução Industrial. Santos (1996) prefere Revolução técnicocientífica. Dreifuss (1996) chama de revolução digital. Revolução informacional é mais apropriada segundo Lojkine (2002), que, a respeito disso, faz o seguinte comentário: 
"Segunda revolução industrial", "revolução científica e técnica", "revolução informática" etc. - a zona de sombra é completa quando se trata de definir a revolução tecnológica que começa. [...] nenhuma dessas designações é adequada [...]. (LOJKINE, 2002, p. 14).

Nota-se uma plurivocidade ${ }^{8}$ dissonante entre os autores. O único aspecto comum é a expressão "revolução", geralmente agregada às conceituações feitas. Porém, revolucionar parece não ser a real função da tecnologia. De acordo com Sampaio (1999), as grandes transformações na sociedade humana, decorrentes da tecnologia, não devem ser entendidas como revolução propriamente dita, visto que não se verificou uma ruptura social e o modo de produção capitalista não findou. Lojkine (2002) escreve que, contrariamente ao comumente pensado, o avanço tecnológico se deu muito mais pela necessidade de se acelerar e expandir o capitalismo e a globalização do capital. Por outro lado, Lévy (1993) constata que as transformações atuais são de tal forma, que novos modos de pensar, de produzir ${ }^{9}$ e de viver estão sendo implementados. Sendo assim, apenas sobre esse aspecto, as transformações merecem ser chamadas de "revolução", porque alteraram e continuam alterando as configurações sócio-espaciais do globo.

Uma das alterações sócio-espaciais que podem ser observadas com a "revolução" trazida pela tecnologia, diz respeito à criação de setores dedicados única e exclusivamente à tecnologia. Como exemplo, pode-se tomar o setor quaternário que, segundo Vesentini (2005a), diferentemente dos setores primário, secundário e terciário, especializa-se, cada vez mais, nas pesquisas de alto nível, entre elas, a aeroespacial, a biotecnologia e a robótica. Para Pinto (2005), isso acontece porque: "Na verdade, a técnica condiciona o destino da técnica".(p. 719). Deduz-se, então, que a tecnologia acaba por condicionar o aparecimento de, cada vez mais, tecnologia.

\footnotetext{
${ }^{8}$ O termo "plurivocidade" foi tirado de Orlandi (1996) e preserva, aqui, o significado original dado pela pensadora, seja ele, o de muitas vozes falando sobre um mesmo assunto. Nesse sentido o termo se aproxima da polifonia de vozes de Bakhtin (1997, p. 4).

${ }^{9}$ É na esfera da produção que as alterações tecnológicas se mostram ainda mais acentuadas. Surge aqui outro encadeamento de conseqüências, com explica Demo (2000): “[...] a educação é cada vez mais imprescindível para criar chances na vida e no mercado, esta mesma educação, reduzida a mero conhecimento a serviço da competitividade, é o motor central da redução das chances." (p. 52). Isso concretamente gera, como impacto, na sociedade, o problema do desemprego. Rifkin (1995) afirma que: “[...] um número crescente de críticos está começando a perguntar "Retreinar para quê?". Com os setores agrícolas, industrial e de serviços automatizando suas operações e tirando milhões [...] de seus empregos [...] a questão sobre onde esses trabalhadores desempregados encontrarão emprego alternativo, uma vez concluído seu retreinamento, torna-se soberana." (p. 38). Por sua vez, Beck (1998) afirma que: "Ningún grupo de cualificación o de profesión ofrece ya protección frente ya desempleo. (p. 119) ("Nenhum grupo de qualificação ou de profissão oferece proteção frente ao desemprego." Tradução nossa). No entanto, os presentes autores não desconhecem teorias de refletem sobre a impossibilidade do fim completo do trabalho. "Para que o trabalho deixasse de ser socialmente central seria preciso um refluxo da relação capital-trabalho em proveito de uma outra relação social que acabaria por suplantá-la, do mesmo modo que a relação capital-trabalho suplantou ou marginalizou as relações sociais que a antecederam." (FREYSSENET, 2000, p. 105).
} 
Parece surgir aqui, e isso vai ao encontro do pensamento de Santos (2006), uma reação causal relacionada à tecnologia. Os presentes autores propõem o seguinte organograma para ilustrar isso (figura 1):

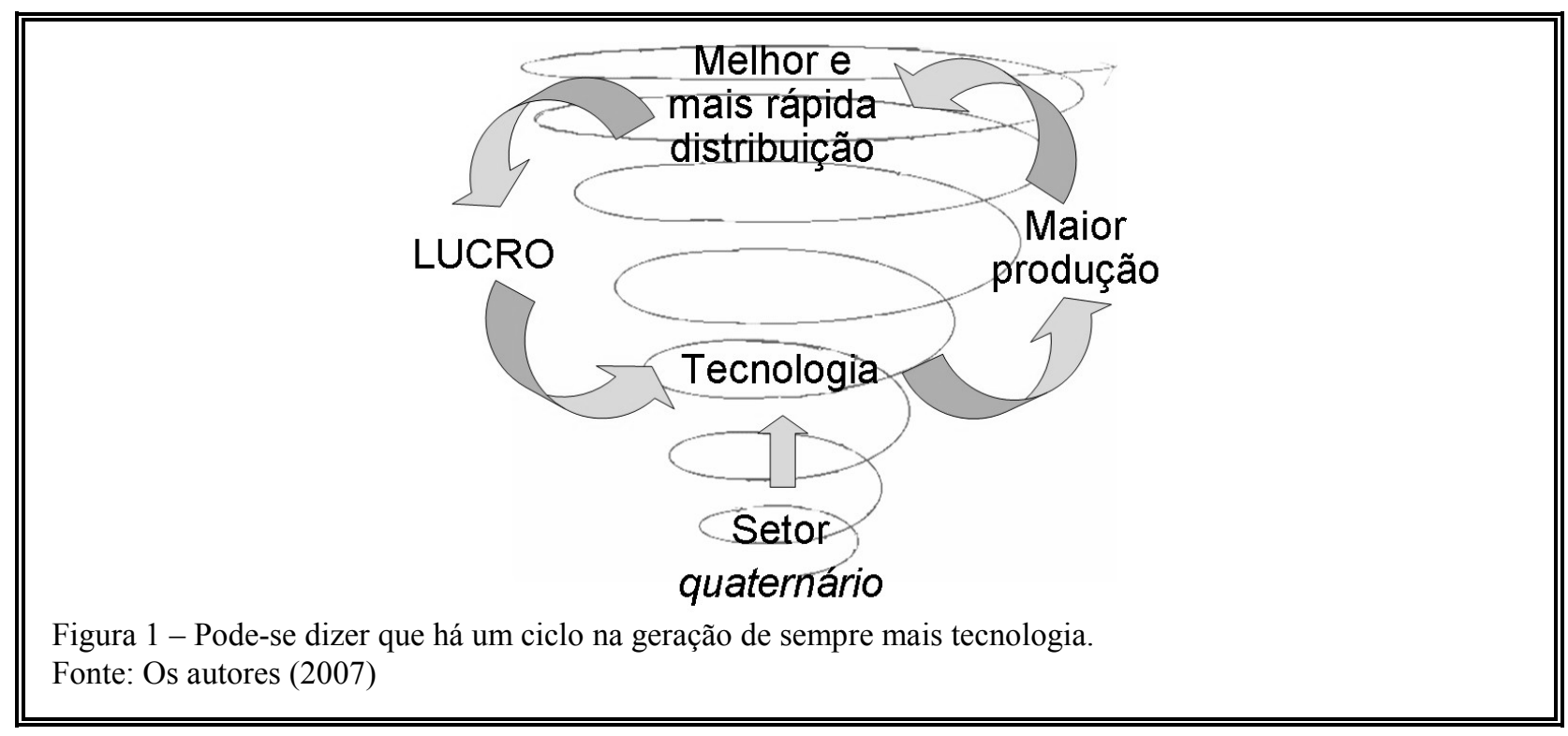

No organograma acima (figura 1) destaca-se o movimento espiralado que há entre o setor quaternário, a geração de tecnologia, a maior produção - sempre buscada -, a melhor e mais rápida distribuição e o lucro. A relação entre os mencionados elementos perfaz um movimento em espiral visto que cresce sempre mais. Em outras palavras, tecnologia gera avanços, tais como, velocidade, maior e melhor produção, os quais, por sua vez, condicionam e necessitam avanços ainda mais velozes, maiores e melhores. Isso é feito para se manter o "crescimento" almejado que deve sempre sublevar o anterior. Constata-se, então, que as atuais atividades encarregadas em gerar tecnologias cada vez mais eficientes, como no caso do setor quaternário, contêm em seu fundamento, a tarefa de suprir a demanda por inovações.

Para Santos (2006), novo acréscimo deve ser feito à constatação de que a tecnologia necessita sempre de mais tecnologia. Nesse sentido, o teórico alude à questão do consumismo despótico agendado ${ }^{10}$ constantemente pela mídia. Segundo Santos (2006):

Nesse caso, o fato gerador do consumo seria a produção. Mas, atualmente, as empresas hegemônicas produzem o consumidor antes mesmo de produzir os

\footnotetext{
${ }^{10}$ O termo "agendamento" (agenda-setting no inglês) foi tirado de Traquina (2001) e conserva aqui o significado original identificado pelo teórico: "Certamente a noção deste conceito, quando surgiu no primeiro artigo de McCombs e Shaw, postulava um poder limitado [da mídia]. Na feliz formulação de Cohen, o conceito do agendamento estipulava inicialmente que os mídia [o texto citado está em português de Portugal] podem não dizer às pessoas como pensar, mas sim sobre o que pensar." (TRAQUINA, 2001, p. 33).
} 
produtos. Um dado essencial do entendimento do consumo é que a produção do consumidor, hoje, precede à produção dos bens de serviços. Então, na cadeia causal, a chamada autonomia na produção cede lugar ao despotismo do consumo. (SANTOS, 2006, p. 48).

Trata-se da produção do consumo alicerçada na autoduplicação da tecnologia legitimada pelo consumismo despótico. Uma antiga pesquisa ${ }^{11}$ (década de 1980) encomendada pelo Ministério de Ciências e Tecnologia ao Instituto Gallup ${ }^{12}$ de Opinião Pública, constatou que, nas regiões urbanas brasileiras, sete entre dez pessoas se interessam por descobertas científicas e tecnológicas, sendo que 31\% dos entrevistados demonstram "muito interesse" (p. 19). A pesquisa aponta, ainda, para muitos outros fatores relacionados à mídia, tais como, o interesse por notícias que versam sobre tecnologia (p. 22), a expectativa quanto à melhoria na comunicação a respeito das tecnologias (p. 26) e a curiosidade sempre crescente por mais informações sobre o assunto (p. 27). A pesquisa constatou que o episódio mais lembrado pelo povo brasileiro, em geral, é o da ida do homem à Lua (p. 33). Não poderia ser diferente pois, como se sabe, foi (e ainda é) fato amplamente veiculado pela mídia.

\begin{abstract}
Daí, o império da informação e da publicidade. Tal remédio teria $1 \%$ de medicina e 99\% de publicidade, mas todas as coisas no comércio acabam por ter essa composição: publicidade + materialidade; publicidade + serviços, e esse é o caso de tantas mercadorias cuja circulação é fundada numa propaganda insistente e frequentemente enganosa. Há toda essa maneira de organizar o consumo para permitir, em seguida, a organização da produção. (SANTOS, 2006, p. 48-49).
\end{abstract}

É notável esse tipo de veiculação, evidenciada por Santos (2006), na mídia. Vejam-se as ilustrações (figuras 2 e 3 ) a seguir:

\footnotetext{
${ }^{11}$ Trata-se da pesquisa publicada pelo nome: O que o brasileiro pensa da ciência e da tecnologia? (a imagem da ciência e da tecnologia junto à população urbana brasileira). MINISTÉRIO DA CIÊNCIA E TECNOLOGIA - CNPq - CONSELHO NACIONAL DE DESENVOLVIMENTO CIENTÍFICO E TECNOLÓGICO, Rio de Janeiro: Museu de Astronomia e Ciências Afins, 1987.

${ }^{12}$ Instituto Gallup de Opinião Pública (The Gallup Organization): trata-se de uma agência de pesquisa fundada, em 1935, pelo psicólogo e jornalista George Horace Gallup (1901-1984). Está sediada em Princeton, no Estado de Nova Jersey, EUA. Possui filiais em pelo menos 27 países. A filial brasileira está em São Paulo.
} 

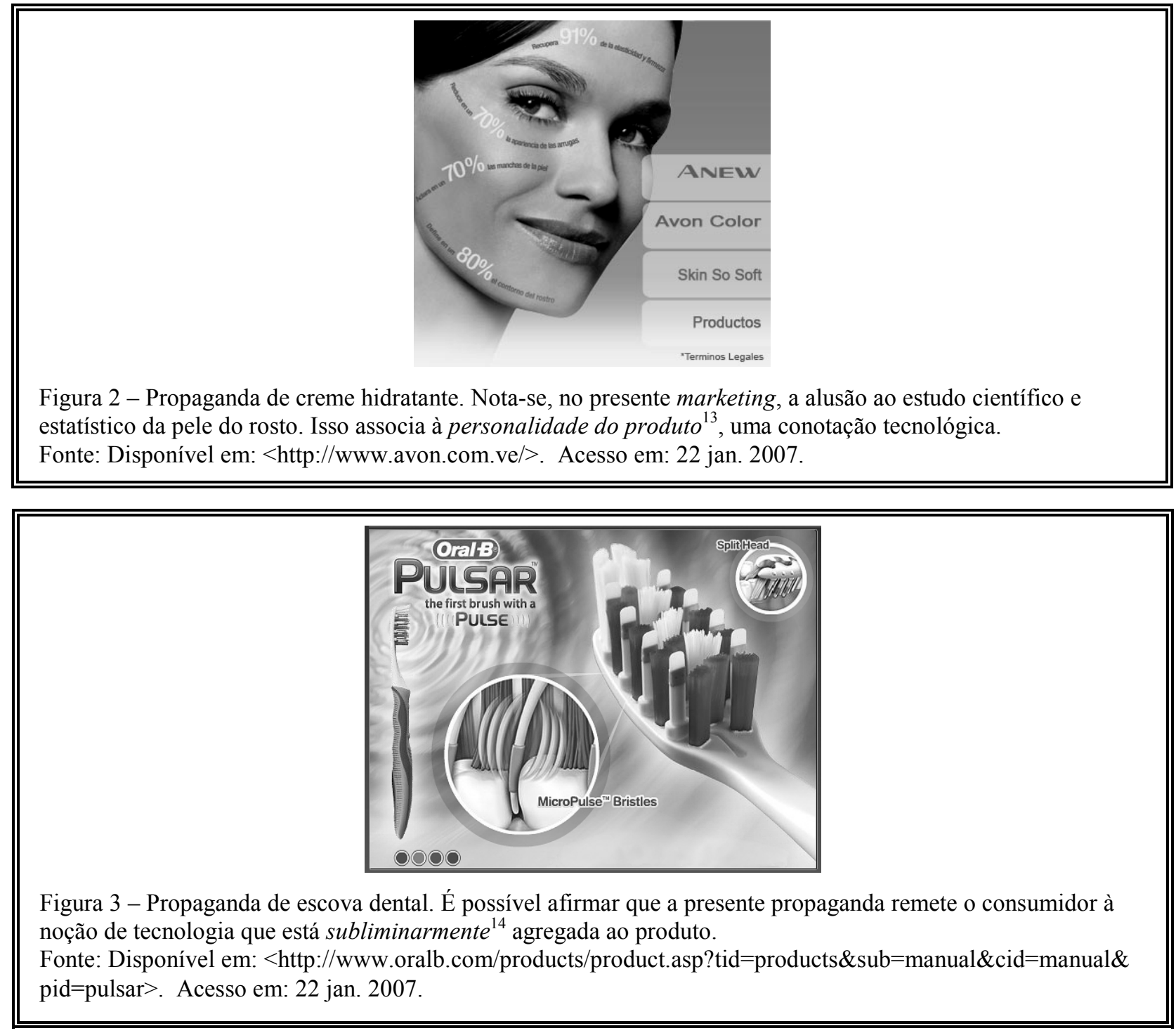

${ }^{13}$ O termo personalidade do produto foi tirado de Ferrés (1998).

${ }^{14} \mathrm{O}$ termo subliminar foi tirado de Mcluhan (1964) e está mais condizente com a seguinte idéia do mesmo autor: "O 'conteúdo' de um meio é como a 'bola' de carne que o assaltante leva consigo para distrair o cão de guarda da mente. O efeito de um meio se torna mais forte e intenso porque o seu 'conteúdo' é um outro meio." (p. 33), ou ainda: "Os anúncios não são endereçados ao consumo consciente. São como pílulas subliminares para o subconsciente, com o fito de exercer um feitiço hipnótico [...]" (p. 257). O termo subliminar é, de certo modo, uma espécie de mito hoje em dia, e, muitas vezes, segundo Calazans (1992), tratado com superficialidade (p. 15). Para este último teórico, "Todas as mídias são subliminares [...]" (p. 29). Ferrés (1998), de sua parte, afirma que: "Se se mede a palavra por sua densidade, mede-se a imagem por seu punch. Se a palavra tende a se impor por seu peso, a imagem se impõe por sua capacidade de choque." (p. 40). Especificamente com relação ao subliminar e às técnicas de posicionamento que os produtos recebem, Ferrés (1998) ainda escreve que estes: "[...] têm como objetivo vincular as necessidades, geralmente psíquicas, do receptor, conferindo personalidade ao produto. Com freqüência, isso é realçado criando para o produto alguns contextos que não têm relação objetiva com o seu valor de uso. De forma inconsciente, o receptor transfere ao produto os valores do contexto. (p. 205). Para ir além, sugere-se ler: CALAZANS, Flávio. Propaganda Subliminar Multimídia. São Paulo: Summus, 1992 e FERRÉS, Joan. Televisão Subliminar: socializando através de Comunicações Desapercebidas. Porto Alegre: Atrmed, 1998. 
Conclui-se, desse modo, que a verdadeira função da tecnologia é esta: a de gerar sempre mais tecnologia, pois atende aos interesses do capital. A tecnologia permite uma maior e melhor produção satisfazendo aos detentores do capital. Essa locupletação cada vez maior do patrão determina a evolução sempre crescente da tecnologia que, como foi visto, surgiu em virtude da busca pelo PODER.

\section{Espacialização da Tecnologia}

A tecnologia não é algo etéreo, desmanchado no ar. Marx e Engels (2001, p. 69) ${ }^{15}$, certa vez escreveram que: "Tudo o que é sólido e estável se volatiliza"16. Os mencionados filósofos, quando expressaram tal pensamento, queriam se referir à capacidade, anteriormente descrita que, entre outras coisas, a tecnologia possui de se transformar ou, segundo Marshal (1986), a chamada "autodestruição inovadora" (p. 97), inerente dos avanços tecnológicos. Isso leva as pessoas, grosso modo, a pensarem na tecnologia como algo abstrato. Porém, defendese aqui, a tecnologia não é algo passível de ser estudado somente na sua dimensão temporal. Ela existe e se dá no espaço e por isso deve ser estudada em suas dimensões espaciais, concretas, portanto. Por outros termos, pretende-se calcar a análise subseqüente de forma que se passe do abstrato ao concreto. Possivelmente no mesmo sentido que colocava Rohden (1987): “O caminho do concreto para o abstrato é inseguro e intransitável - mas o caminho do abstrato para o concreto é seguro e sempre transitável”.(p. 153).

Sabe-se que a tecnologia dispõe hoje de um setor especialmente dedicado à sua geração/duplicação, e que a mesma não fica confinada à uma única esfera. Acaba por ser transferida à todos os demais setores. De acordo com Caron (2001), além de a tecnologia estar presente em laboratórios e centros de pesquisa, está presente, também, nos mais variados tipos de indústria:

\footnotetext{
${ }^{15}$ A versão consultada foi: MARX, Karl e ENGELS, Friedrich. Manifesto do Partido Comunista. Tradução Marco Aurélio Nogueira e Leandro Konder. Petrópolis: Vozes, 2001. 151 p. Título Original: Manifest der Kommunistischen Partei.

${ }^{16}$ Os presentes autores concordam com o fato de que: "Marx sempre tratou a técnica e a ciência de modo parcial e subordinado." (ROMERO, 2005, p. 16). Porém, "reside justamente nisso uma das qualidades de sua concepção.” (ROMERO, 2005, p. 16). Segundo Berman (1986): “[...] a verdade é que, como Marx o vê, tudo que a sociedade burguesa constrói é construído para ser posto abaixo. 'Tudo o que é sólido' - das roupas sobre nossos corpos aos teares e fábricas que as tecem, aos homens e mulheres que operam as máquinas, às casas e aos bairros onde vivem os trabalhadores, às firmas e corporações que os exploram, às vilas e cidades regiões inteiras e até mesmo nações que as envolvem - tudo isso é feito para ser desfeito amanhã, despedaçado ou esfarrapado, pulverizado ou dissolvido, a fim de que possa ser reciclado ou substituído na semana seguinte e todo o processo possa seguir adiante, sempre adiante, talvez para sempre, sob formas cada vez mais lucrativas." (p. 97). Para ir além, ler: BERMAN, Marshall. Tudo que é sólido desmancha no ar: a aventura da modernidade. Tradução Carlos Felipe Moisés. São Paulo: Companhia das Letras, 1992. 360 p. Título Original: All that is Solid Melts into Air.
} 
A ciência mais fundamental encontra-se de agora em diante presente na fábrica, não somente em setores de alta tecnologia, como a eletrônica ou a biotecnologia, mas também em setores de tecnologia média, tais como o automóvel [...] intensificaram suas relações com universidades e os centros de pesquisa. (CARON, 2001, p. 414).

A intensificação das relações entre empresas e setores econômicos identificada por

Caron (2001) pode ser observada tomando-se o exemplo das parcerias entre universidades e empresas. Vide imagem abaixo (figura 4):

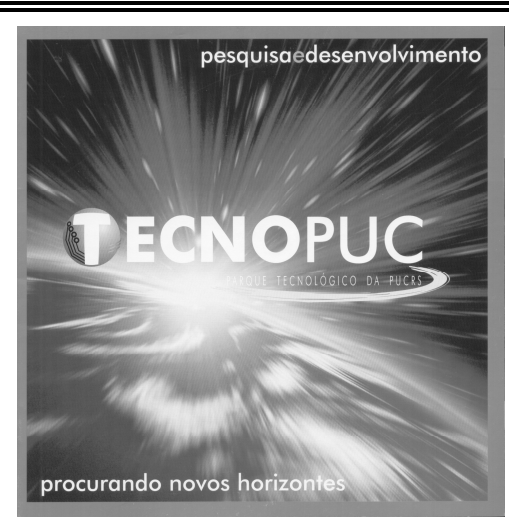

Figura 4 - Folder publicitário do Parque Tecnológico da Pontifícia Universidade Católica do Rio Grande do Sul. O parque conta, atualmente, com 40 empresas e 12 instituições, dentre as quais se destacam as multinacionais Microsoft ${ }^{\circledR}$, Dell Computers ${ }^{\mathrm{TM}}, H P\left(\right.$ Hewlett-Packard) ${ }^{\circledR}$ e Siemens ${ }^{\circledR}$.

Fonte: AGEXPP - PUCRS/FAMECOS.

É nítido na ilustração acima (figura 4) o apelo à questão relacionada à pesquisa e ao desenvolvimento e, também, aos "novos horizontes". As construções de áreas específicas, os chamados "parques tecnológicos", são exemplos do supramencionado processo. Multinacionais e universidades trabalham em regime de parceria na implementação de tecnologias, alterando, desse modo, a conformação sócio-espacial:

A corporação estratégica age como breakthrough enterprise, orientada para a produção pelo seu coração tecnológico, o qual define a possibilidade de oferecer produtos de composição politecnológica, de utilização múltipla (produto e instrumento, bem e serviço). Além de possuir uma capacidade de aplicação multissetorial das suas destrezas e saberes tecnológicos e de ser capaz de integrar seus produtos-serviços como componentes essenciais da produção - em "famílias" de produtos existentes ou em gestação e em clusters resultantes dos vários entrecruzamentos tecnológicos - de outras corporações.

$[\ldots]$

Este inovador sistema produtivo "pesquisa-intensivo" é potencializado pelas ações corporativas - de alcance supra-regional, transnacional e interempresarial, que (re)concentram e "reposicionam" capital, tecnologia, recursos humanos e infraestrutura - deslanchadas através do funcionamento sinergético de unidade, redes e cadeias de criação, produção e comercialização, balizadas por subsistemas administrativo-legais de planejamento e gestão [...] (DREIFUSS, 1996, p. 46). 
Antigamente, essas ações corporativas eram impossíveis. Segundo Caron (2001), esse fenômeno só se dá porque as indústrias adquiriram uma enorme mobilidade espacial. Quando da Primeira Revolução Industrial, as indústrias permaneciam "presas" às fontes de recursos naturais. A "localização das usinas dependia estreitamente das fontes de energia utilizada [...]. Os transportes públicos também esbarravam num limite bastante grave.” (p. 411). Atualmente, a proximidade às fontes de energia e recursos naturais não é mais necessária às indústrias e o transporte já é algo praticamente resolvido, possibilitando uma flexibilidade industrial nunca antes vista.

No processo de intensificação e distribuição da tecnologia houve rápida substituição das velhas por novas. Caron (2001) afirma que durante a Primeira Revolução Industrial a máquina a vapor já não supria mais as necessidades da sociedade que despontava. Exigiam-se, então, inovações para uma maior/melhor eficiência na produção, bem como no escoamento dessa produção. O advento da eletricidade, segundo Caron (2001), trouxe novo salto produtivo. A eletricidade permitiu novas perspectivas e caracterizou nova etapa da evolução tecnológica. Em concordância com Vesentini (2005), pode-se dizer que, a eletricidade possibilitou a instauração da chamada Segunda Revolução Industrial. Para Caron (2001), a luz elétrica que chegava permitia a dissipação das trevas. Possibilitava, entre outras coisas, às novas populações urbanas a sua fixação nas cidades. A luz permitia, também, e, sobretudo, uma maior e mais eficiente produção.

Ao longo da história, muitas outras inovações proporcionaram melhorias na produção, sendo que, ainda hoje, as mais marcantes são as que "encurtam" o espaço e "diminuem" o tempo. Vide, abaixo, o chamado "encolhimento do mapa" proposto por Harvey (2004) (figura 5):

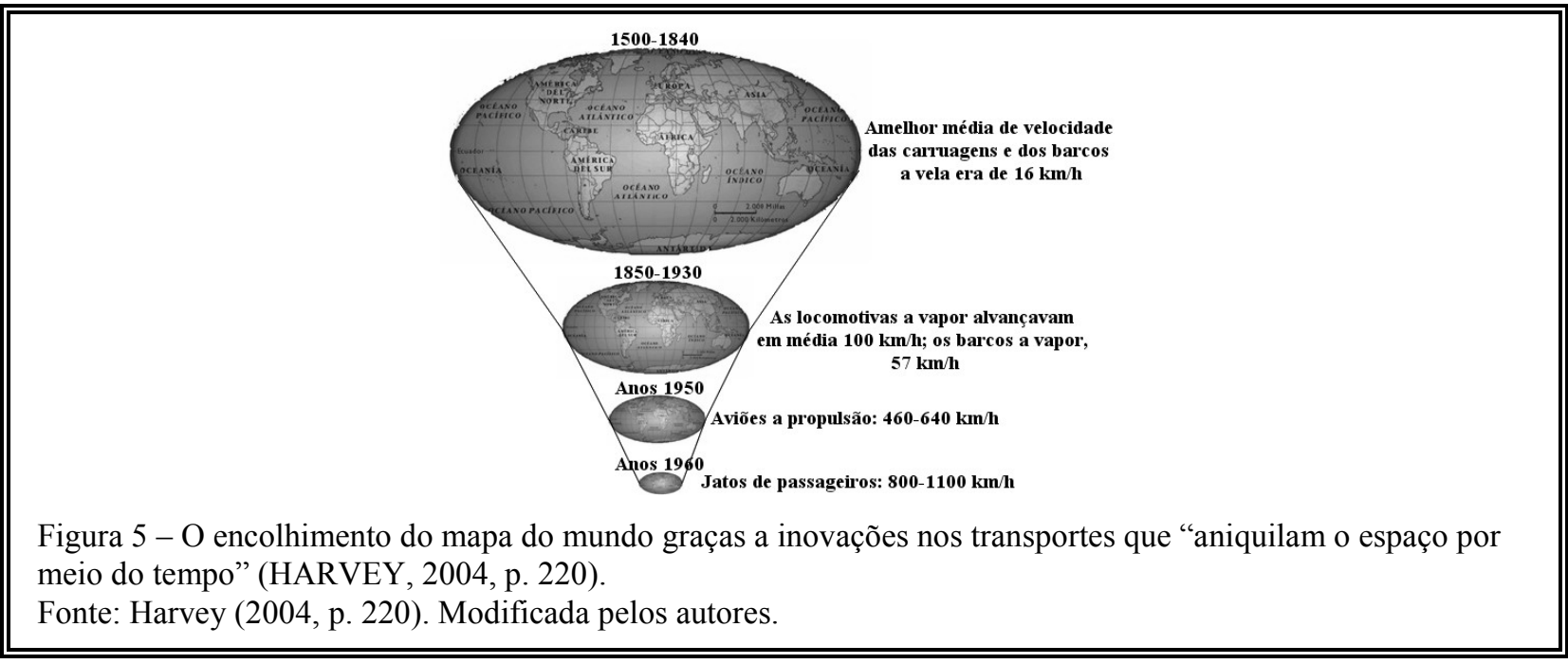


A ilustração acima (figura 5) gerou bastante estranhamento à época de sua proposta ${ }^{17}$. Ela, de certa forma, propõe o fim de uma categoria importante, seja ela, o espaço. No mesmo ano, Fukuyama (1992) apresentava algo análogo, decretando, com o seu "O fim da História" ${ }^{18}$, a derrocada de outra categoria importante, desta vez, o tempo. O próprio Fukuyama (1992) explica:

[...] o que eu sugeria não era o fim da ocorrência dos eventos, nem dos fatos grandes e importantes, mas da História, ou seja, da história como um processo único, coerente e evolutivo, considerando a experiência de todos os povos em todos os tempos. (FUKUYAMA, 1992, p. 11).

Mais recentemente Friedman (2005), aproveitando as idéias de Harvey (2004) e, com base na velocidade permitida pela tecnologia e na terceirização dos serviços proporcionada pela globalização do trabalho, conclui que o mundo é plano. O teórico propõe, implicitamente, que quanto mais avança a tecnologia mais "encolhe" e se "aplaina" o globo. Pode-se visualizar mais organizada e sistematizadamente o argumento supramencionado, da seguinte forma:

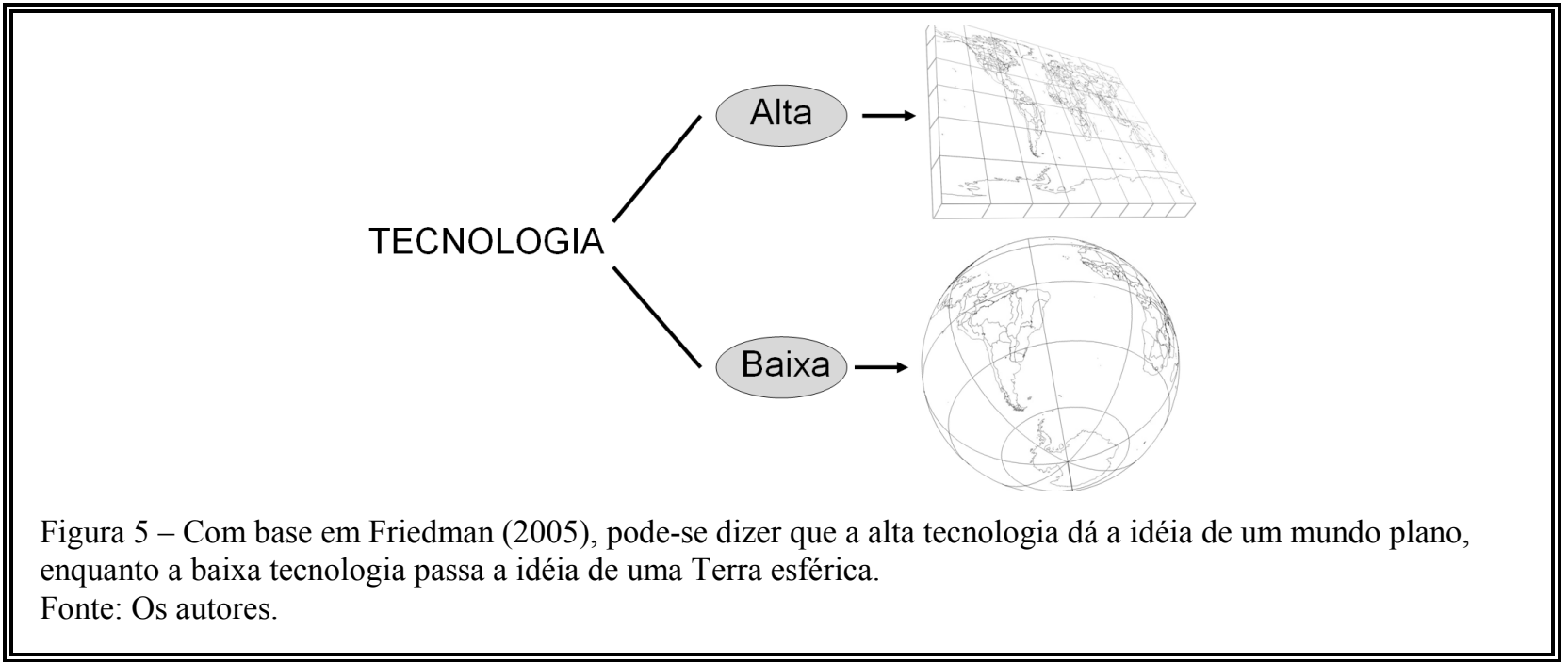

\footnotetext{
${ }^{17}$ A primeira edição do "The Condition of Postmodernity An Enquiry into the Origins of Cultural Change" foi lançada em 1989.

${ }^{18} \mathrm{O}$ artigo intitulado "The end of History" foi publicado em 1989 na revista The Nacional Interest e assumiu a forma de um livro no ano de 1992. Ver: "FUKUYAMA, Francis. The end of history? The National Interest Magazine, Chicago, n. 16, p. 3-16, 1989" e FUKUYAMA, Francis. O Fim da História e o Último Homem. Tradução Aulyde Soares Rodrigues. Rio de Janeiro: Rocco, 1992. 489 p. Título Original: The End of History and the Last Man.
} 
A ilustração acima (figura 5) vai ao encontro de argumentações que defendem o paradigma de um mundo cada vez mais dinâmico ${ }^{19}$ plano e interconectado, onde não há mais “desníveis altimétricos” advindos de uma desigualdade tecnológica.

Santos (1996), a respeito das inovações que proporcionaram aumento da velocidade, escreve que:

O fim do século XIX, com a formação dos grandes impérios, marca um momento fundamental nesse desenvolvimento. A estada de ferro, o navio a vapor, o telégrafo sem fio, a evolução bancária mudam completamente a noção de distância e, como conseqüência, as escalas de tempo e espaço. Nessa definição de momentos marcantes da história da humanidade, chegamos à época atual comandada pela revolução científico-tecnológica. (SANTOS, 1996, p. 166).

Nos dias atuais os transportes são extremamente velozes. Não apenas os transportes de mercadorias, mas, também, os da informação ${ }^{20}$. A circulação da informação na infovia se dá num volume muito maior e num tempo infinitamente menor, tendendo a "encolher-se" ainda mais o "espaço por meio do tempo" (HARVEY, 2004, p. 220) com o proporcional aumento do volume e da velocidade de transporte da informação. Os presentes autores propõem que, levada em conta a velocidade de circulação de uma correspondência eletrônica (E-Mail), ou seja, tomando-se por base, apenas a circulação da informação, o "encolhimento do mapa do mundo" proposto por Harvey (2004) estaria mais condizente com a imagem abaixo (figura 6):

19 Em outro trabalho pertinente, Giddens (1991), coloca que: "O dinamismo da modernidade deriva da separação do tempo e do espaço e de sua recombinação em formas que permitem o "zoneamento" tempoespacial preciso da vida; do desencaixe dos sistemas sociais (um fenômeno intimamente vinculado aos fatores envolvidos na separação tempo-espaço); e da ordenação e reordenação reflexiva das relações sociais à luz das contínuas entradas (inputs) de conhecimento afetando as ações de indivíduos e grupos.” (p. 25). Para saber mais sobre a noção de desencaixe espaço-temporal ver: "GIDDENS, Anthony. As conseqüências da Modernidade. São Paulo: Editora UNESP, 1991.”, especialmente às páginas 25 à 37.

${ }^{20}$ Segundo Lojkine (2002): “Cabe a Henri Laborit o mérito de ter especificado o conceito de informação a partir de sua experiência como biólogo. Opondo o sistema fechado da termodinâmica e da matéria inerte ao sistema aberto da estrutura da viva, ele definiu a informação - à moda de Norbert Wiener (1962) - como o que não é nem massa nem energia. A informação necessita da massa e da energia como suporte, mas, em si, ela é imaterial [...]” (p. 113). Wiener (1954), por sua vez, define informação como sendo: “[...] termo que designa o conteúdo daquilo que permutamos com o mundo exterior ao ajustar-nos a êle, e que faz com que nosso ajustamento seja nêle percebido. $O$ processo de receber e utilizar informação é o processo de nosso ajuste às contingências do meio ambiente e de nosso efetivo viver nesse meio ambiente. As necessidades e a complexidade da vida moderna fazem, a êste processo de informação, exigências maiores do que nunca, e nossa imprensa, nossos museus, nossos laboratórios científicos, nossas universidades, nossas bibliotecas e nossos compêndios estão obrigados a atender às necessidades de tal processo, sob pena de malograr em seus escopos.” (p. 17-18). 


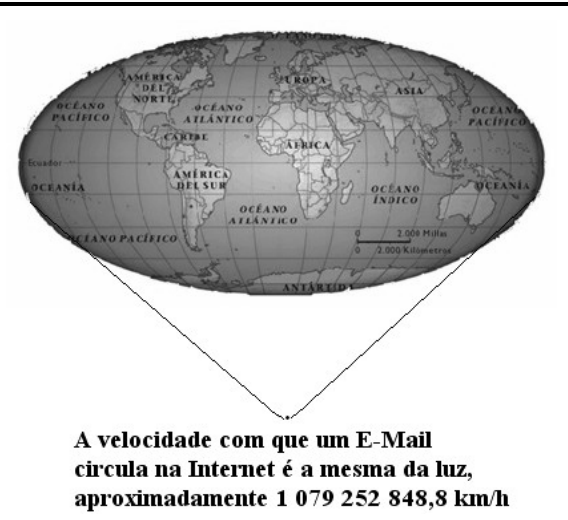

Figura 6 - O espaço e o tempo tornam-se, praticamente inexistentes na comunicação eletrônica. A informação circula na mesma velocidade da radiação eletromagnética.

Fonte: Os autores

$\mathrm{Na}$ infovia, a informação viaja a uma velocidade tão alta que em softwares de conversação eletrônica, também chamados de chat, é possível a habitantes antípodas no globo, a comunicação em tempo imediato. Sabe-se que, se um avião viajasse nesta velocidade, circundaria sete vezes a Terra em, aproximadamente, um segundo. É nesse sentido, entre outros, que Dreifuss (1996) escreve ser esta, a época das perplexidades. Costella (2002) coloca que:

Aldous Huxley disse que o mundo moderno inventou um novo vício: a velocidade. De fato, nos últimos séculos o homem se empenhou em uma desabalada corrida de superações contínuas. Em todos os setores do conhecimento humano observa-se esse fenômeno de aceleração, com tendência sempre mais crescente, por força de efeitos multiplicadores de ordem exponencial. E é na área da comunicação que se desnuda, mais patente o "vício" moderno. Uma notícia que, há duzentos anos, era transportada à velocidade do cavalo, pode hoje, mercê das conquistas eletrônicas, saltar oceanos e continentes com a rapidez da eletricidade. (COSTELLA, 2002, p. 93).

Segundo Mattelard (2000) e Caron (2001), no passado, as populações que assistiam à ampliação dos avanços tecnológicos tinham a impressão de que tudo seria melhor, a tecnologia viria para melhorar a qualidade de vida das sociedades. Porém, na realidade, a tecnologia caracterizou-se pela rápida obsolescência daqueles que eram incorporados no processo produtivo. As tecnologias, com todo o conforto delas decorrente foram ficando cada vez mais elitizadas e apenas um seleto grupo passou, desde então, a ter acesso ao consumo desses bens. Hoje, segundo Mattelard (2000), é possível se falar em "tecno-apartheid", visto 
que, no caso da Internet, por exemplo, "só 2\% da população mundial estavam em 1999 ligada à rede das redes.” (p. 157) ${ }^{21}$. Kawamura (1990) chama a atenção, destacando que:

[...] a evidente diferenciação no acesso aos benefícios decorrentes das inovações tecnológicas nas diversas áreas econômico-sociais e culturais, restritos a reduzidas parcelas da população. Em contrapartida, proporções crescentes desta sistematicamente e progressivamente excluídas do processo de trabalho, do acesso aos sofisticados serviços médicos, culturais e de lazer; dos centros de estudo e difusão científica e tecnológica. (KAWAMURA, 1990, p. 11).

De forma semelhante, Giddens (2005) aponta para um mundo repleto de incoerências. Avanços que não geram as melhorias reais na sociedade e, pelo contrário, acabam por dar uma sensação de que vivemos num mundo em descontrole:

\footnotetext{
Nossa época se desenvolveu sob o impacto da ciência, da tecnologia e do pensamento racional [...]

$[\ldots]$

Os filósofos do iluminismo observaram um preceito simples mas obviamente poderoso. Quanto mais formos capazes de compreender racionalmente o mundo, e a nós mesmos, mais poderosamente poderemos moldar a história para nossos propósitos.

$[\ldots]$

O mundo em que nos encontramos hoje, no entanto, não se parece muito com o que eles previram. Em vez de estar cada vez mais sobre nosso comando, parece um mundo em descontrole. Além disso, algumas das influências que, supunham-se antes, iriam tornar a vida mais segura e previsível para nós, entre elas o progresso da ciência e da tecnologia, tiveram muitas vezes o efeito totalmente oposto. A mudança do clima regional e os riscos que a acompanham, por exemplo, resultam provavelmente de nossa intervenção no ambiente. (GIDDENS, 2005, p. 13-14).
}

Parece que a tecnologia não surgiu para facilitar a vida da população em geral, mas sim para que uma pequena parte dela pudesse ser beneficiada. Para Singer (1975), a partir do momento que a máquina passou a substituir o homem, fundou-se o capitalismo e o lucro exacerbado advindo desse processo ${ }^{22}$. A introdução de máquinas nas atividades dos trabalhadores permitiu, aos patrões, maiores lucros em função de menores custos de produção, sem falar no desemprego. Com as máquinas era necessário muito menos tempo para se produzir muito mais. É a chamada mais-valia relativa (SANDRONI, 1982; DEMO, 2000).

\footnotetext{
${ }^{21}$ Os presentes autores não ignoram a opinião de teóricos renomados, tais como, Lévy (2001) que colocam que a tecnologia, em específico a Internet, está se espalhando numa velocidade muito maior do que a de outros meios à sua época, como, por exemplo, a carta, o telefone e outros que, comparativamente, demoraram muito mais tempo para serem popularizados. Porém, ainda assim, sabe-se que é coreto afirmar a existência de uma forte exclusão tecnológica. O próprio Lévy (2001) adverte que: "Estima-se freqüentemente que o desenvolvimento da cibercultura poderia ser uma fator suplementar de desigualdade e de exclusão, tanto entre classes de uma sociedade como entre nações de países ricos e pobres. Esse risco é real.” (p. 235-236).

${ }_{22}$ Quanto a isso Freyssennet (2000) faz um complemento precioso: "De facto, a divisão do 'know-how" sobre o trabalho é bem anterior ao taylorismo e remonta, pelo menos, ao nascimento do capitalismo e do salariato. Impôs-se na organização produtiva e na concepção das máquinas porque os proprietários e os dirigentes não podiam ter certeza de obter dos seus assalariados a produção - em quantidade, qualidade, custos e demoras para a qual tinham investido seu capital." (p. 104).
} 
Entrementes, as "melhorias" inventivas com as quais os trabalhadores se deparam no trabalho, dificilmente são verificadas, proporcionalmente, em suas casas. É perfeitamente possível, por exemplo, verificar um trabalhador assalariado cumprir sua jornada de trabalho num avançado estabelecimento, shopping, por exemplo, e não dispor de saneamento básico na periferia onde mora. Nos países pobres, tais como o Brasil, é mais correto se categorizar o padrão de vida de algumas pessoas dentro de contextos do século XIX, do que encaixá-los no atual século (SAMPAIO, 1999, p. 17).

Às supracitadas incoerências acrescenta-se a constatação de que os pobres, bem ou mal, são obrigados a "interagirem” com avanços que eram impensados há décadas atrás. Os caixas eletrônicos dos bancos, onde os aposentados "sacam" seu salário mínimo mensal, é exemplo prático disso. Parece haver, neste ponto, uma imposição tecnológica. É nesse sentido que Lévy (1993) escreve que esses processos de inserção tecnológica na vida das populações raramente (para não se dizer nunca) são objeto de decisões coletivas. Para Kawamura (1990), mesmo num país pobre como o Brasil, com dificuldades de desenvolvimento e dependente em muitos aspectos, a tecnologia já está no dia-a-dia das pessoas. Freire (1996) desfere dura crítica a esse processo ao escrever que:

O progresso científico e tecnológico que não responde fundamentalmente aos interesses humanos, às necessidades de nossa existência, perdem, para mim, sua significação. A todo avanço tecnológico haveria de corresponder o empenho real de resposta imediata qualquer desafio que pusesse em risco a alegria de viver dos homens e das mulheres. [...] esta é uma questão ética e política e não tecnológica. O problema me parece muito claro. Assim como não posso usar minha liberdade de fazer coisas, de indagar, de agir, de criticar para esmagar a liberdade dos outros de fazer e de ser, assim também não poderia ser livre para usar os avanços científicos e tecnológicos que levam milhares de pessoas à desesperança. Não se trata, acrescentamos, de inibir a pesquisa e frear os avanços mas de pô-los a serviço dos seres humanos. A aplicação de avanços tecnológicos com o sacrifício de milhares de pessoas é um exemplo a mais de quanto podemos ser transgressores da ética universal do ser humano e o fazemos em favor de uma ética pequena, a do mercado, a do lucro. (FREIRE, 1996, 147-148).

Como se pode ver, para Freire (1996), a tecnologia não está, ainda, a serviço dos seres humanos. No entanto, a vida do homem está espacialmente transfigurada, repleta de artefatos tecnológicos. Dos caixas eletrônicos dos bancos aos computadores com acesso à Internet; dos relógios de punho aos telefones celulares, praticamente tudo que o homem manipula, o coloca em contato com a tecnologia.

\section{Considerações Finais}


O presente artigo procurou apresentar algumas considerações a respeito da tecnologia. Sobre as origens de tal termo, a etimologia propriamente dita, foram apresentados alguns aspectos que, via de regra, nem sempre são lembrados nos círculos acadêmicos. Tal mergulho na origem do termo permite fazer a correta apreciação acerca do sentido primeiro que tal conceito deveria ter, e, também, efetuar algumas diferenciações que permanecem, igualmente, nebulosas como, por exemplo, a diferenciação necessária entre técnica e tecnologia, geralmente considerados, erroneamente, como sinônimos.

Com as reflexões sobre o surgimento, evolução e função da tecnologia, os presentes autores buscaram (re)lembrar questões pertinentes à vontade de poder ${ }^{23}$ inerente ao ser humano e que, de certa forma, está associada a situação de inferioridade física que o homem possui se comparado aos outros animais do globo. Neste mesmo tópico chamou-se a atenção para a relação espiralada e cíclica que a tecnologia tem e que permite mais e mais a criação de novos avanços.

Com o tópico sobre a espacialização da tecnologia, o texto procurou trazer à tona a importância que as categorias espaço e tempo têm na produção e distribuição das inovações, bem como, dar relevo a questões relacionadas aos diversos modos de entender e perceber a espacialidade e a temporalidade.

Conclui-se o presente artigo chamando a atenção para o fato de que a tecnologia deve sempre ser tomada sob um ponto de vista crítico. Diabolizar ou divinizar a tecnologia trata-se de um erro (FREIRE, 1996). Sendo assim, tomá-la como algo essencialmente bom ou essencialmente ruim não é o modo correto de pensar. Cumpre analisá-la sob o ponto de vista dialógico e colocá-la em sua devida esfera, qual seja, na de ferramenta que permite ao homem fazer-se mais forte enquanto ser humano mesmo e não o de escravizar e oprimir outros homens. Em outras palavras, o presente artigo procurou trazer reflexões pertinentes e que colaborem em fazer com que o "machado" (evocado por Einstein na epígrafe) volte a ser a ferramenta capaz de fazer o bem.

\section{Referências}

BAKHTIN, Mikhail Mikhailovitch. Problemas da Poética de Dostoiévski. 2. ed. Rio de

\footnotetext{
${ }^{23} \mathrm{O}$ termo vontade de poder foi tirado de Nietzsche (2005, p. 27). Ver: "NIETZSCHE, Friedrich. Além do bem e do mal: prelúdio de uma filosofia do futuro. Tradução Paulo César Souza. São Paulo: Companhia das Letras, 2005. 247 p. Título Original: Jenseints von Gut Böse. Vorspiel einer Philosophie der Zukunft.” especialmente às páginas 26 à 40 .
} 
Janeiro: Forense Universitária, 1997.

BECK, Ulrich. La sociedad del risco. Hacia uma nueva modernidad. Barcelona: Paidós, 1998.

BERMAN, Marshall. Tudo que é sólido desmancha no ar: a aventura da modernidade. Tradução Carlos Felipe Moisés. São Paulo: Companhia das Letras, 1992. 360 p. Título Original: All that is Solid Melts into Air.

BRÜSEKE, Franz Josef. A técnica e os riscos da modernidade. Florianópolis: Ed. Da UFSC, 2001.

CALAZANS, Flávio. Propaganda Subliminar Multimídia. São Paulo: Summus, 1992.

CARON, Francis in MORIN, Edgard. A Religação dos Saberes: desafio do século XXI, São Paulo: Bertrand Brasil, 2001.

CHAUÍ, Marilena. O que é ideologia. São Paulo: Brasiliense, 1997.

COSTELLA, Antonio F. Comunicação do grito ao satélite: (história dos meios de comunicação). 5. ed. Campos do Jordão: Editora Mantiqueira, 2002.

DEMO, Pedro. Educação e Conhecimento: Relação necessária, insuficiente e controversa. Petrópolis: Vozes, 2000.

DICIONÁRIO ESCOLAR LATINO-PORTUGUÊS. [S.1.: s.n.], 1962.

DICIONÁRIO DE FILOSOFIA DE CAMBRIDGE. São Paulo: Paulus, 2006.

DREIFUSS, René Armand. A época das perplexidades: mundialização, globalização e planetarização: novos desafios. Petrópolis: Vozes, 1996.

FERRÉS, Joan. Televisão Subliminar: socialização através de comunicações desapercebidas. Porto Alegre: Artmed, 1998.

Pedagogia da Esperança: um reencontro com a pedagogia do oprimido. 11. ed. São Paulo: Paz e Terra, 1992.

Pedagogia da Autonomia: saberes necessários à prática educativa. 7. ed. São Paulo: Paz \& Terra, 1996.

FREYSSENET, Michel. A crise e as transformações das formas de emprego não significam o fim do trabalho. In: O Novo Estado do Mundo: 80 idéias-força pata entrar no século XXI. Porto: Campo das Letras, 2000.

FRIEDMAN, Thomas L. O mundo é plano: Uma breve história do século XXI. Rio de Janeiro Objetiva, 2005. 
FUKUYAMA, Francis. O Fim da História e o Último Homem. Tradução Aulyde Soares Rodrigues. Rio de Janeiro: Rocco, 1992. 489 p. Título Original: The End of History and the Last Man.

GIDDENS, Anthony. As Conseqüências da Modernidade. São Papulo: Editora UNESP, 1991.

Mundo em Descontrole: o que a globalização está fazendo de nós. 4. ed. Rio de Janeiro: Record, 2005.

HARVEY, David. Condição Pós-Moderna. 13. ed. São Paulo: Loyola, 2004.

HUNT, E. K., SHERMAN, Howard J. História do Pensamento Econômico. Petrópolis: Vozes, 1997.

KAWAMURA, Lili. Novas Tecnologias e Educação. São Paulo: Ática, 1990.

LÉVY, Pierre. As Tecnologias da Inteligência: o futuro do pensamento na era da informática. Rio de Janeiro: Editora 34, 1993.

Cibercultura. 2. ed. São Paulo: Editora 34, 2001.

LOJKINE, Jean. A Revolução Informacional. 3. ed. São Paulo: Cortez, 2002.

MATTELARD, Armand. A Comunicação representa um novo horizonte das utopias totalizantes, incorporando a aposta do "progresso infinito". In: O Novo Estado do Mundo: 80 idéias-força pata entrar no século XXI. Porto: Campo das Letras, 2000.

MARX, Karl e ENGELS, Friedrich. Manifesto do Partido Comunista. Tradução Marco Aurélio Nogueira e Leandro Konder. Petrópolis: Vozes, 2001. 151 p. Título Original: Manifest der Kommunistischen Partei.

MCLUHAN, Marshal. Os meios de comunicação como extensões do homem. São Paulo: Cultrix, 1964.

MORAIS, João Francisco Regis de. Filosofia da ciência e da Tecnologia: Introdução metodológica e crítica. 5. ed. Campinas: Papirus, 1988.

NIETZSCHE, Friedrich. Além do bem e do mal: prelúdio de uma filosofia do futuro. Tradução Paulo César Souza. São Paulo: Companhia das Letras, 2005. 247 p. Título Original: Jenseints von Gut Böse. Vorspiel einer Philosophie der Zukunft.

O QUE O BRASILEIRO PENSA DA CIÊNCIA E DA TECNOLOGIA? (a imagem da ciência e da tecnologia junto à população urbana brasileira). MINISTÉRIO DA CIÊNCIA E TECNOLOGIA - CNPq - CONSELHO NACIONAL DE DESENVOLVIMENTO CIENTÍFICO E TECNOLÓGICO, Rio de Janeiro: Museu de Astronomia e Ciências Afins, 1987.

ORLANDI, Eni Puccinelli. Interpretação; autoria, leitura e efeito do trabalho simbólico. Petrópolis: Vozes, 1996. 
PAPERT, Seymour. A Máquina das Crianças. Repensando a Educação na Era da Informática. Porto Alegre: Artes Médicas, 1994.

O Conceito de Tecnologia. Rio de Janeiro: Contraponto, 2005. 1v.

RIFKIN, Jeremy. O fim dos empregos: do declínio inevitável dos níveis dos empregos e a redução da força global de trabalho. São Paulo: Makron Books, 1995.

ROHDEN, Humberto. Einstein: O enigma do Universo. $5^{\text {a }}$ ed. São Paulo: Ed. Alvorada. 1987.

ROMERO, Daniel. Marx e a técnica: um estudo dos manuscritos de 1861-1863. São Paulo: Expressão Popular, 2005.

SAMPAIO, Marisa Narciso. Alfabetização tecnológica do professor. Petrópolis, RJ: Vozes, 1999.

SANDRONI, Paulo. O que é mais valia. São Paulo: Brasiliense, 1982.

SANTOS, Milton. Por uma Nova Geografia. São Paulo: 4. ed. Hucitec, 1996.

Por uma outra globalização: do pensamento único à consciência universal. Rio de Janeiro: 13. ed. Record, 2006.

SINGER, P. Curso de Introdução à Economia Política. Rio de Janeiro, FORENSE, 1975, p. 132.

TRAQUINA, Nelson. O Estudo do Jornalismo no Século XX. São Leopoldo: Unisinos, 2001 .

WIENER, Norbert. Cibernética e Sociedade: O uso Humano de Seres Humanos. São Paulo: Cultrix, 1954.

VESENTINI, José William. Sociedade e Espaço: geografia geral e do Brasil. São Paulo: Ática, 2005. 